\title{
Efektivitas Pelatihan Teknologi Budidaya Bawang Putih Varietas Lokal Ramah Lingkungan dengan Metode Ceramah di Kabupaten Karanganyar
}

\author{
D $01: 10.18196 /$ agr.2126
}

\begin{abstract}
Garlic (Allium Sativum L.) is a vegetable that has a lot of profit because its high economic value. Garlic consumption from year to year increases with population growth, but this increase has not matched with an increase in production due to many constraints such as pest attack. Training for garlic farmer aims to improve farmers' knowledge in the application of garlic environmentally friendly cultivation technology. Training of farmers was conducted on 14 April 2015 using the lecture method. The purpose of this study was to determine the effectiveness of the training model using the lecture method to garlic farmers in Karanganyar. The samples used were 20 farmers from the garlic farmers in Karanganyar. Purposive sampling was
\end{abstract}

used as sampling technique. The study was conducted by giving pretest and postest to determine the increase farmers' knowledge, then the data were analyzed using non-parametric statistical analysis (Wilcoxon Match Pairs Test). The results showed that the value of the $Z$ count on the Wilcoxon test was 3.106 an absolute value. Furthermore, the error level of $5 \%, Z$ table $=1.64$ so that the $Z$ count is greater than $Z$ table. This shows that training the farmers by using lecture method in Karanganyar was effective to improve the knowledge of the farmers.

Keywords: effectiveness, training, garlic.

\section{INTISARI}

Bawang putih (Allium sativum L.) merupakan sayuran yang banyak mendatangkan keuntungan karena mempunyai nilai ekonomi tinggi. Kebutuhan konsumsi bawang putih dari tahun ke tahun meningkat dengan meningkatnya jumlah penduduk, namun peningkatan ini belum diimbangi oleh peningkatan produksi karena banyak kendala antara lain serangan OPT. Pelatihan terhadap petani bawang putih bertujuan untuk meningkatkan pengetahuan petani dalam penerapan teknologi budidaya bawang putih ramah lingkungan. Pelatihan terhadap petani dilakukan pada 14 April 2015 menggunakan metode ceramah. Tujuan dari penelitian ini adalah mengetahui efektivitas model pelatihan menggunakan metode ceramah kepada petani bawang putih di Kabupaten Karanganyar. Jumlah sampel yang digunakan sebanyak 20 orang dari petani bawang putih di Kabupaten Karanganyar. Tehnik pengambilan sampel menggunakan metode purposive sampling. Penelitian dilakukan dengan memberikan pretest dan postest untuk mengetahui peningkatan pengetahuan petani, selanjutnya data tersebut dianalisis menggunakan analisis statistik non parametrik yaitu uji Wilcoxon Match Pairs Test. Hasil penelitian menunjukkan bahwa harga Z hitung pada uji Wilcoxon adalah -3,106 merupakan nilai mutlak. Selanjutnya pada taraf kesalahan $5 \%$, Z tabel = 1,64 sehingga Z hitung lebih besar dari Z tabel. Hal 
ini menunjukkan bahwa pelatihan petani menggunakan metode ceramah di Kabupaten Karanganyar efektif dalam meningkatkan pengetahuan peserta pelatihan.

Kata kunci: efektivitas, pelatihan, bawang putih.

\section{PENDAHULUAN}

Bawang putih (Allium sativum L.) merupakan sayuran yang banyak mendatangkan keuntungan karena mempunyai nilai ekonomi tinggi. Kebutuhan konsumsi bawang putih dari tahun ke tahun meningkat dengan meningkatnya jumlah penduduk, namun peningkatan ini belum diimbangi oleh peningkatan produksi karena banyak kendala antara lain serangan organisme pengganggu tanaman (OPT).

Dalam menghadapi pasar bebas seperti Masyarakat Ekonomi ASEAN (MEA) 2015, bidang pertanian dituntut untuk dapat menghasilkan produk yang aman

dikonsumsi dengan mutu yang lebih baik dan tidak berdampak negatif terhadap lingkungan. Menindaklajuti tuntutan tersebut, sudah saatnya petani menjadi perhatian serius bagi pemerintah, salah satunya dengan meningkatkan pengetahuan dan ketrampilan petani. Pengetahuan adalah hasil dari tahu dan ini terjadi setelah seseorang melakukan penginderaan terhadap suatu objek tertentu. Tanpa pengetahuan seseorang tidak memiliki dasar untuk mengambil keputusan dan menentukan tindakan terhadap masalah yang dihadapi. Faktor-faktor yang mempengaruhi pengetahuan antara lain adalah pendidikan, pekerjaan, umur, minat, pengetahuan dan informasi (Anonim, 2014).

Peningkatan pengetahuan petani dilakukan melalui berbagai metode. Menurut Hamalik (2005), secara umum pelatihan bertujuan untuk mempersiapkan dan membina tenaga kerja, baik struktural maupun fungsional, yang memiliki kemampuan dalam profesinya, kemampuan melaksanakan loyalitas, dedikasi dan disiplin yang baik. Menurut Sastradipoera (2006) konsep pelatihan sebagai salah satu bentuk proses pembelajaran yang berhubungan dengan upaya pengubahan tingkah laku sumber daya manusia agar tingkah laku itu sesuai dan memadai untuk kebutuhan dan tujuan tertentu.

Salah satu metode yang digunakan dalam penyuluhan pertanian (pelatihan) adalah metode ceramah. Menurut Peraturan Menteri Pertanian Nomor : 52/Permentan/ OT.140/12/ 2009 tentang Metode Penyuluhan Pertanian, metode ceramah adalah penyampaian informasi secara lisan kepada pelaku utama, pelaku usaha dan/atau tokoh masyarakat dalam suatu pertemuan. Menurut penelitian yang dilakukan oleh Ooi, et al. (2007), faktor yang paling berkontribusi terhadap efektivitas pelatihan adalah kompetensi trainer dan metode pelatihan. Hal ini diperkuat oleh penelitian yang dilakukan Haslinda (2009) bahwa kompetensi instruktur dan jenis pelatihan merupakan faktor yang signifikan berkontribusi terhadap efektivitas pelatihan. Menurut Suwarto (1999), efektivitas artinya adanya efek (pengaruh, akibat, dan kesan) pada penggunaan metode/cara, sarana/alat dalam melaksanakan aktivitas sehingga berhasil guna (mencapai hasil yang optimal). Melalui pelatihan diharapkan pengetahuan petani dapat meningkat sehingga petani dapat menerapkan teknologi budidaya bawang putih ramah lingkungan.

Berdasarkan latar belakang tersebut di atas, maka perlu dilakukan penelitian yang bertujuan untuk mengetahui efektivitas model pelatihan menggunakan metode ceramah yang diberikan kepada petani bawang putih di Kabupaten Karanganyar. Keefektifan dapat juga diartikan suatu ukuran yang menyatakan seberapa jauh target (kuantitas, kualitas dan waktu) yang telah dicapai. Dengan demikian semakin tinggi kadar keefektifan maka semakin tinggi pula tingkat capaian kuantitas, kualitas dan waktu pencapaianya (Anonim, 2014). Hasil dari penelitian ini selanjutnya dapat digunakan sebagai instrumen pendekatan dalam memperbaiki dan penyempurnaan program/kegiatan penyuluhan pertanian sehingga lebih efektif, efisien dan dapat mencapai tujuan yang telah ditetapkan.

\section{METODE PENELITIAN}

Penelitian dilaksanakan di Kabupaten Karanganyar pada tanggal 14 April 2015. Populasi dalam penelitian ini adalah 20 petani bawang putih Kecamatan Tawangmangu, Kabupaten Karanganyar. Pengambilan sampel sebanyak 20 petani bawang putih dilakukan secara sengaja (purposive sampling). Petani yang dipilih merupakan petani bawang putih yang sudah lama (turun temurun) melakukan budidaya bawang putih dengan teknik budidaya secara umum dan sederhana yaitu belum menggunakan teknologi ramah lingkungan.

Penelitian ini dilakukan dengan mengukur pengetahuan petani bawang putih sebelum dan sesudah mengikuti pelatihan dengan menggunakan metode ceramah. Metode ceramah yang dilaksanakan diperkaya dengan teknik-teknik pengaktifan peserta misalnya 
TABEL I. KARAKTERISASI PEtANI BAWANG PUTIH KECAMATAN tAWANGMANGU, KABUPATEN KARANGANYAR

\begin{tabular}{llllll}
\hline $\begin{array}{l}\text { Usia } \\
\text { (Tahun) }\end{array}$ & $\sum$ (Orang) & $\begin{array}{l}\text { Tingkat } \\
\text { Pendidikan }\end{array}$ & $\sum$ (Orang) & $\begin{array}{l}\text { Lama Berusahatani } \\
\text { (Tahun) }\end{array}$ & $\sum$ (Orang) \\
\hline $36-46,5$ & 11 & SD & 3 & $5-20$ & 14 \\
$47-57,5$ & 7 & SLTP & 5 & $21,5-36,5$ & 5 \\
$58-68$ & 2 & SLTA & 10 & $37-50$ & 1 \\
& & D3 & 1 & & \\
& & S1 & 1 & & \\
\hline
\end{tabular}

diskusi atau tanya jawab. Menurut Mujiman (2006), pelatihan dengan menggunakan metode ceramah yang diperkaya dengan teknik-teknik pengaktifan peserta misalnya diskusi atau tanya jawab akan mengaktifkan dan memotivasi peserta dalam pemahaman dan penguasaan materi yang diberikan. Alat ukur yang digunakan dalam penelitian ini adalah kuisioner pretest dan postest.

Kuisioner berupa pertanyaan dengan penilaian secara skoring mengenai materi teknologi budidaya bawang putih ramah lingkungan. Kuisioner pretest dan posttes yang digunakan sama. Pertanyaan yang digunakan sebagai variabel dalam pengukuran efektivitas pelatihan meliputi pengetahuan/pemahaman tentang: (i) Cara budidaya bawang putih ramah lingkungan; (ii) Penggunaan benih bersertifikat dalam mendukung budidaya bawang putih ramah lingkungan; (iii) Cara mendapatkan benih yang sehat; (iv). Cara mendapatkan pupuk organik yang baik; (v) Penggunaan pupuk dalam budidaya bawang putih yang ramah lingkungan; (vi) Pembuatan guludan/bedengan yang ramah lingkungan; (vii) Penggunaan pestisida yang baik agar sesuai dengan kaidah ramah lingkungan; (viii) Agensia hayati; (ix) Cara mendapatkan agensia hayati; (x) Penggunaan agensia hayati dan aplikasinya; dan (xi) Cara mengelola pengendalian hama dan penyakit dalam satu kawasan atau pengendalian secara terpadu. Dari setiap varabel atau pertanyaan akan dilakukan skoring/ penilaian dengan interval $1-3$ dengan kriteria, skor 1 menunjukkan nilai tinggi, skor 2 menunjukkan nilai sedang, dan skor 3 menunjukkan nilai rendah.

Pelatihan dilakukan selama tujuh jam dimulai jam 09.00 - 16.00 WIB. Materi yang disampaikan berupa teknologi budidaya bawang putih ramah lingkungan hasil kajian dan dijadikan rekomendasi teknologi yang meliputi: penggunaan varietas yang unggul dan baik, pupuk organik plus, rekomendasi pemupukan, penggunaan mulsa, jarak tanam, penggunaan agensia hayati, dan sistem tanam.

Data primer yang dihimpun terdiri dari karakteristik responden dan hasil pretest dan postest. Data dianalisis dengan perangkat lunak aplikasi SPSS 17, menggunakan analisis statistik, dengan uji Wilcoxon Match Pairs Test (Siegel, 1994 dan Sugiyono, 2010). Uji ini digunakan untuk mengetahui perbedaan pengetahuan peserta antara sebelum dan sesudah diberikan pelatihan.

\section{HASIL DAN PEMBAHASAN}

\section{KERAGAAN RESPONDEN}

Respoden dalam penelitian ini adalah peserta pelatihan, yaitu petani bawang putih dari Kecamatan Tawangmangu Kabupaten Karanganyar. Seluruh responden berjenis kelamin laki-laki, namun terdapat keragaman karakteristik responden dari aspek usia dan pendidikan (Tabel 1).

Berdasarkan Tabel 1 seluruh responden, secara umum masuk dalam usia produktif yaitu 36 - 64 tahun yaitu sebanyak 19 responden, sedangkan 1 responden sudah masuk usai non produktif (68 tahun). Untuk tingkat pendidikan sebanyak 50 persen responden adalah SLTA. Seluruh responden merupakan petani bawang putih yang telah memiliki pengalaman berusahatani cukup lama, namun demikian penerapan berusahatani dilakukan secara turun temurun sehingga belum menerapkan budidaya ramah lingkungan. Mardikanto (2009) dalam bukunya tentang sistem penyuluhan pertanian menyebutkan bahwa karakterisitik penerima manfaat (petani) pada kegiatan penyuluhan (pelatihan) sangat menentukan dalam pemahaman dan pengetahuan petani yang meliputi: (i) karaktrsiktik pribadi (jenis kelamin, umur, suku/etnis, dan agama); (ii) status sosial ekonomi 
TABEL 2. HASIL PRE TEST DAN POST TEST

\begin{tabular}{lll|lll}
\hline Responden & Pre Test & Post Test & Responden & Pre Test & Post Test \\
\hline 1 & 15 & 27 & 11 & 17 & 33 \\
2 & 16 & 33 & 12 & 16 & 33 \\
3 & 15 & 27 & 13 & 15 & 33 \\
4 & 11 & 33 & 14 & 13 & 27 \\
5 & 11 & 33 & 15 & 15 & 33 \\
6 & 17 & 33 & 16 & 17 & 33 \\
7 & 16 & 33 & 17 & 13 & 33 \\
8 & 12 & 33 & 18 & 15 & 33 \\
9 & 13 & 33 & 19 & 15 & 33 \\
10 & 16 & 33 & 20 & 14 & 33 \\
\hline Total Pre test & \multicolumn{7}{l|}{} & Total Post test & 642 \\
Rata-rata & 292 & 14,6 & Rata-rata & 32,1 \\
\hline
\end{tabular}

(tingkat pendidikan, tingkat pendapatan, dan keterlibatan dalam kelompok); (iii) perilaku keinovasian; dan (iv) moral sosial (petani subsisten atau petani komersial).

Usia responden yang sebagain besar masuk dalam kategori usia produktif lebih cenderung memiliki sifat keinovasian dan motivasi yang tinggi dalam adopsi inovasi teknologi baru. Lama berusaha tani juga menentukan pemahaman terhadap materi yang berikan, responden tinggal membandingkan dengan apa yang telah dilakukan dengan teknologi baru. Pemahaman tentang teknologi baru dapat diperkuat melalui diskusi antara nara sumber dan petani (responden) sehingga dapat menyakinkan dalam penerapan teknologi baru yang disampaikan. Moral sosial petani (responden) sebagai petani komersial juga menjadi faktor penentu dalam adposi teknologi baru, yaitu keinginan untuk mendapatkan keuntungan dari penerapan teknologi baru; dibandingkan dengan petani subsisten yang hanya mengandalkan teknologi turun temurun, tanpa ada inovasi dalam pengembangan teknologi dalam berusaha tani.

\section{EFEKTIVITAS PELATIHAN (MENGGUNAKAN METODE CERAMAH)}

Untuk mengetahui efektifitas model pelatihan menggunakan metode ceramah dilakukan dengan pengisian kuisioner pretest oleh responden sebelum pelatihan dimulai. Peningkatan pengetahuan responden setelah pelatihan diukur menggunakan kuisioner postest yang diisi oleh responden setelah pelatihan selesai dilaksanakan. Penilaian setiap materi pada kusioner dengan skoring, yaitu dengan nilai tertinggi 3 dan nilai terendah 1 , kemudian nilai tersebut dijumlahkan sebagai nilai akhir. Hasil dari pengisian kuisioner pretest dan postest tersaji pada Tabel 2 .

Data selanjutnya dianalisis dengan aplikasi SPSS 17, menggunakan analisis statistik nonparametrik yaitu dengan uji Wilcoxon Match Pairs Test. Hasil dari analisis data yang dilakukan tersaji pada Tabel 3. Analisis data dilakukan dengan membandingkan nilai hasil pre test dan post test untuk menguji signifikansi dua subyek penelitian berpasangan (Ernawati, et al, 2012). Analisis uji Wilcoxon Match Pairs Test merupakan analisis pengujian efektivitas (Narbuko, 2004).

TABEL 3. ANALISIS STATISTIK UJI WILCOXON MATCH PAIRS

\begin{tabular}{lllll}
\hline & N & Mean Rank & $\begin{array}{l}\text { Sum of } \\
\text { Ranks }\end{array}$ \\
\hline Postes - Pretes & Negative Ranks & $0^{a}$ & 0,00 & 0,00 \\
& Positive Ranks & $20^{b}$ & 10,50 & 210,00 \\
& Total & 20 & & \\
Z & & & $-3,929^{b}$ \\
Asymp. Sig. (2-tailed) & & & 0,000 \\
a. Postes $<$ Pretes & & & \\
b. Postes $>$ Pretes & & & \\
\hline
\end{tabular}


Hasil analisis uji Wilcoxon dengan $\mathrm{n}=20$, taraf kesalahan 5 persen menunjukkan nilai Asymp. Sig. 0,000 (Asymp. Sig. d" 0,05). Harga Z hitung pada uji Wilcoxon adalah -3,929 merupakan nilai mutlak. Selanjutnya pada taraf kesalahan 5 persen, $Z$ tabel $=1,64$ sehingga $Z$ hitung lebih besar dari $Z$ tabel. Hal ini menunjukan bahwa pelatihan yang dilakukan menggunakan metode ceramah berpengaruh signifikan dalam meningkatkan pengetahuan peserta pelatihan.

Sebelum dilakukan pelatihan tentang teknologi budidaya bawang putih ramah lingkungan terlebih dahulu telah dilakukan identifikasi teknologi eksisting di tingkat petani untuk mengetahui materi yang sesuai dengan kondisi di tingkat petani tentang teknologi ramah lingkungan melalui PRA (Partispatoris Rural Apprasial). Dari data PRA tersebut secara umum, responden (petani) belum menggunakan teknologi budidaya bawang putih ramah lingkungan. Perbedaan teknologi budidaya bawang putih ramah lingkungan dan teknologi budidaya bawang eksisting di tingkat petani yang disampaikan pada pelatihan dapat dilihat pada Tabel 4 .

Materi yang diberikan dalam pre test dan post test merupakan pertanyaan tentang budidaya bawang putih ramah lingkungan secara umum. Materi yang digunakan sebagai variabel/pertanyaan dalam pengukuran efektivitas pelatihan meliputi pengetahuan/pemahaman tentang hal-hal sebagai berikut.

1. Budidaya bawang putih ramah lingkungan (P1);

2. Penggunaan benih bersertifikat dalam mendukung budidaya bawang putih ramah lingkungan (P2);

3. Cara mendapatkan benih yang sehat (P3);

4. Cara mendapatkan pupuk organik yang baik (P4);

5. Penggunaan pupuk dalam budidaya bawang putih yang ramah lingkungan (P5);

6. Pembuatan guludan/bedengan yang ramah lingkungan (P6);

7. Penggunaan pestisida yang baik agar sesuai dengan kaidah ramah lingkungan (P7);

8. Tentang agensia hayati (P8);

9. Cara mendapatkan agensia hayati (P9);

10. Penggunaan agensia hayati dan aplikasinya (P10); dan

11. Cara mengelola pengendalian hama dan penyakit dalam satu kawasan atau pengendalian secara terpadu (P11).

Perkembangan pengetahuan responden (petani) dapat dilihat dari perbedaan nilai yang diperloleh dari nilai masing-masing materi yang diberikan hasil dari penilaian pre test (sebelum mengikuti pelatihan) dan post test (setelah mengikuti pelatihan). Berikut peningkatan

\section{TABEL 4. PERBEDAAN TEKNOLOGI BUDIDAYA BAWANG PUTIH RAMAH LINGKUNGAN DAN EKSISTING DI TINGKAT PETANI}

\begin{tabular}{|c|c|c|c|}
\hline No & Materi & $\begin{array}{l}\text { Teknologi } \\
\text { Ramah Lingkungan }\end{array}$ & $\begin{array}{l}\text { Teknologi eksisting } \\
\text { di tingkat petani }\end{array}$ \\
\hline 1 & Benih & Bersertifikat sehingga dijamin lebih sehat dan lebih murni & $\begin{array}{l}\text { Didapatkan turun temurun sehingga ada kecenderungan membawa } \\
\text { OPT dari umbi sebelumnya dan kurang murni }\end{array}$ \\
\hline 2 & $\begin{array}{l}\text { Pupuk organik yang } \\
\text { digunakan }\end{array}$ & $\begin{array}{l}\text { Sudah matang dan mengandung agensi hayati yaitu trichoderma dan } \\
\text { PGPR }\end{array}$ & Terkadang kurang matang dan tidak mengandung agensia hayati \\
\hline 3 & $\begin{array}{l}\text { Pupuk anorganik yang } \\
\text { digunakan }\end{array}$ & $\begin{array}{l}\text { Sesuai dengan kebutuhan dengan melihat unsur tanah (hasil } \\
\text { laboratorium, keadaan tanaman, dan kondisi wilayah) }\end{array}$ & $\begin{array}{l}\text { Mengikuti pola pemupukan turun temurun sehingga terkadang } \\
\text { berlebihan }\end{array}$ \\
\hline 4 & Guludan/ Bedengan & $\begin{array}{l}\text { Sesuai dengan kontur/ kemiringan tanah, lebar guludan, dan jarak } \\
\text { antar guludan serta jarak tanam, diharapkan penggunaan pupuk } \\
\text { sesuai kebutuhan dan hasil dapat optimal }\end{array}$ & $\begin{array}{l}\text { Sudah menyesuaikan kontur/ kemiringan tanah, namun lebar } \\
\text { guludan, jarak antar guludan, dan jarak tanaman masih dengan pola } \\
\text { lama/turun temurun sehingga penggunaan pupuk yang boros dan } \\
\text { hasil kurang optimal }\end{array}$ \\
\hline 5 & Penggunaan pestisida & $\begin{array}{l}\text { Dilakukan apabila diperlukan jika terjadi serangan OPT (sudah } \\
\text { dilakukan aplikasi dengan agensia hayati) }\end{array}$ & $\begin{array}{l}\text { Dilakukan sebelum dan pada waktu serangan OPT sehingga } \\
\text { pemakaian berlebihan }\end{array}$ \\
\hline 6 & Penggunaan agensia hayati & $\begin{array}{l}\text { a. Trichoderma dan PGPR pada pupuk organik } \\
\text { b. Penyemprotan dengan Beuavira dan Trichoderma }\end{array}$ & $\begin{array}{l}\text { Belum pernah menggunakan agensia hayati untuk mengendalikan } \\
\text { OPT }\end{array}$ \\
\hline 7 & $\begin{array}{l}\text { Pengendalian OPT secara } \\
\text { terpadu }\end{array}$ & $\begin{array}{l}\text { Melalui kelompok tani bersama-sama dengan pemantauan petugas } \\
\text { POPT di tingkat kecamnatan }\end{array}$ & $\begin{array}{l}\text { Masih melakukan sendiri-sendiri berdasarkan pengalaman masing- } \\
\text { masing dan hanya melihat anjuran yang ada pada label }\end{array}$ \\
\hline
\end{tabular}


pengetahuan peserta pelatihan hasil pre test dan post test dapat dilihat pada Tabel 5.

\section{TABEL 5. PERKEMBANGAN PENGETAHUAN PETANI BERDASARKAN MATERI PRE TEST DAN POST TEST YANG DIBERIKAN}

\begin{tabular}{llll}
\hline Materi & Pre Test & Post Test & $\begin{array}{l}\text { Peningkatan } \\
(\%)\end{array}$ \\
\hline P1 & 28 & 58 & 51,72 \\
P2 & 29 & 59 & 50,85 \\
P3 & 27 & 59 & 54,24 \\
P4 & 31 & 58 & 46,55 \\
P5 & 27 & 58 & 53,45 \\
P6 & 22 & 59 & 62,71 \\
P7 & 31 & 58 & 46,55 \\
P8 & 22 & 59 & 62,71 \\
P9 & 21 & 58 & 63,79 \\
P10 & 31 & 59 & 47,46 \\
P11 & 23 & 57 & 49,65 \\
\hline Jumlah & 292 & 642 & 54,52 \\
\hline
\end{tabular}

Dari Tabel 5 dapat dilihat bahwa rata-rata pengetahuan responden (petani) mengenai budidaya bawang putih ramah lingkungan setelah pelatihan mengalami peningkatan sebesar 54,52 persen. Hal ini juga dapat dilihat pada grafik di bawah ini.

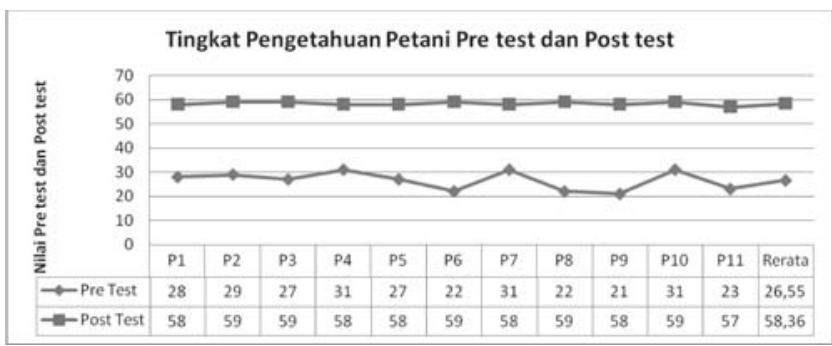

Peningkatan pengetahuan petani melalui pelatihan ini tidak terlepas dari peran dari narasumber yang berkompeten dalam memberikan materi tentang teknologi budidaya bawang putih ramah lingkungan, hal ini diperkuat oleh penelitian yang dilakukan Haslinda et al. (2009) bahwa kompetensi instruktur merupakan faktor yang signifikan berkontribusi terhadap efektivitas pelatihan. Nara sumber yang menyampaikan materi berasal dari BPTP Jawa Tengah yang merupakan peneliti hama dan penyakit tanaman hartikultura dan peneliti ilmu tanah (pemupukan) tanaman hortikultura serta pemulia dan peneliti hortikultura khususnya bawang putih dari Balai Penelitian Sayuran (Balitsa) Lembang, Jawa Barat. Peserta pelatihan yang merupakan petani yang berpengalaman dalam budidaya bawang putih juga merupakan faktor penting yang berpengaruh dalam meningkatnya pengetahuan peserta pelatihan, sebagaimana yang disampaikan Anonim (2014) bahwa faktor-faktor yang mempengaruhi pengetahuan antara lain adalah pendidikan, pekerjaan, umur, minat, pengetahuan dan informasi.

Setelah pelaksanaan pelatihan, selain diberikan pertanyaan dalam post test, reponsden (petani) juga diminta untuk memberikan penilaian terhadap materi untuk mengetahui sikap dan respon selanjutnya. Penilaian diberikan terkait dengan: manfaat materi yang diberikan, kemudahan materi untuk diterapkan, kelebihan keuntungan yang didapat dalam penerapan materi, kesesuaian materi dengan kebutuhan usahatani, kesukaan atau ketertarikan terhadap materi yang diberikan, keinginan untuk menerapkan materi yang diberikan, dan rencana penerapan materi yang telah diberikan (Tabel 6).

Tabel 6 menujukkan bahwa dari ketujuh kriteria sikap dan respon terhadap materi yang diberikan secara umum dinilai pada katerogi tinggi yaitu 100 persen. Namun demikian untuk kriteria kemudahan materi dalam penerapannya 30 persen responden menilai pada kategori sedang. Hal ini menunjukkan bahwa responden (petani) belum terlalu yakin terhadap kemudahan dalam penerapan materinya, untuk itu, sebagai tindak lanjut dibutuhkan pendampingan dalam penerapan teknologi budidaya.

Sementara itu, untuk kriteria kelebihan keuntungan yang didapat dalam penerapan materi, 40 persen responden menilai pada kategori sedang. Hal ini menunjukkan bahwa responden (petani) belum melihat langsung kelebihan keuntungan dalam penerapan materi. Sebagai tindak lanjutnya akan dilakukan demplot sehingga petani akan dapat merasakan dan melihat langsung kelebihan dan keuntungan yang diperoleh dalam menerapkan teknologi budidaya bawang putih ramah lingkungan.

Untuk kriteria rencana penerapan materi yang telah diberikan, 45 persen responden menilai pada kategori tinggi, 35 persen menilai pada kategori sedang, dan 20 persen menilai pada kategori rendah. Perbedaan kategori ini berdasarkan pada tingkatan rencana responden (petani) dalam rencana penerapannya yaitu: (i) kategori 
tinggi artinya responden (petani) berencana akan mencoba menerapkan sendiri, mencoba merapkan di kelompok tani, dan menyampaikan kepada petani lain di pertemuan kelompok; (ii) kategori sedang artinya responden (petani) berencana akan mencoba sendiri dan di kelompok tani; dan (iii) kategori rendah artinya responden (petani) hanya berencana akan mencoba sendiri.

TABEL 6. SIKAP DAN RESPON TERHADAP MATERI YANG DIBERIKAN

\begin{tabular}{|c|c|c|c|c|}
\hline No & Kriteria & Skor & $\sum$ Resp & $(\%)$ \\
\hline \multirow[t]{3}{*}{1} & Manfaat materi yang & $1-1,66$ & 0 & 0 \\
\hline & diberikan & $1,67-2,33$ & 0 & 0 \\
\hline & & $2,34-3$ & 20 & 100 \\
\hline \multirow[t]{3}{*}{2} & Kemudahan materi untuk & $1-1,66$ & 0 & 0 \\
\hline & diterapkan & $1,67-2,33$ & 6 & 30 \\
\hline & & $2,34-3$ & 14 & 70 \\
\hline \multirow[t]{3}{*}{3} & Kelebihan keuntungan & $1-1,66$ & 0 & 0 \\
\hline & yang didapat dalam & $1,67-2,33$ & 8 & 40 \\
\hline & penerapan materi & $2,34-3$ & 12 & 60 \\
\hline \multirow[t]{3}{*}{4} & Kesesuaian materi & $1-1,66$ & 0 & 0 \\
\hline & dengan kebutuhan & $1,67-2,33$ & 0 & 0 \\
\hline & usahatani & $2,34-3$ & 20 & 100 \\
\hline \multirow[t]{3}{*}{5} & Kesukaan atau & $1-1,66$ & 0 & 0 \\
\hline & ketertarikan terhadap & $1,67-2,33$ & 0 & 0 \\
\hline & materi yang diberikan & $2,34-3$ & 20 & 100 \\
\hline \multirow[t]{3}{*}{6} & Keinginan untuk & $1-1,66$ & 0 & 0 \\
\hline & menerapkan materi yang & $1,67-2,33$ & 0 & 0 \\
\hline & diberikan & $2,34-3$ & 20 & 100 \\
\hline \multirow[t]{3}{*}{7} & Rencana penerapan & $1-1,66$ & 4 & 20 \\
\hline & materi yang telah & $1,67-2,33$ & 7 & 35 \\
\hline & diberikan & $2,34-3$ & 9 & 45 \\
\hline
\end{tabular}

Keterangan: $1=$ Rendah; 2 = Sedang; $3=$ Tinggi

\section{KESIMPULAN}

Analisis uji Wilcoxon dengan membandingkan pengetahuan peserta pelatihan melalui pretes dan postes menunjukkan pelatihan secara signifikan meningkatkan pengetahuan peserta. Hasil penelitian membuktikan bahwa model pelatihan menggunakan metode ceramah efektif dalam meningkatkan pengetahuan petani tentang teknologi budidaya bawang putih ramah lingkungan di Kabupaten Karanganyar.

Peningkatan pengetahuan responden (petani) setelah mengikuti pelatihan rata-rata sebesar 54,52 persen. Untuk sikap dan respon secara umum dinilai pada kategori tinggi yaitu: (i) manfaat materi yang diberikan sebesar 100 persen; (ii) kemudahan materi untuk diterapkan sebesar 70 persen; (iii) kelebihan keuntungan yang didapat dalam penerapan materi sebesar 60 persen; (iv) kesesuaian materi dengan kebutuhan usahatani sebesar 100 persen; (v) kesukaan atau ketertarikan terhadap materi yang diberikan sebesar 100 persen; (vi) keinginan untuk menerapkan materi yang diberikan sebesar 100 persen; dan (vii) rencana penerapan materi yang telah diberikan sebesar 45 persen.

\section{UCAPAN TERIMA KASIH}

Sumber dana penelitian berasal dari DIPA Badan Litbang Pertanian Jakarta dan BPTP Jawa Tengah TA. 2015. Ucapan Terima kami ucapkan kepada tim KKP3SL Bawang Putih BPTP Jawa Tengah tahun 2015 dan narasumber pelatihan dari Balai Penelitian Sayuran Lembang, Laboratorium Pengawasan Hama dan Penyakit Sukoharjo, BPTP Jawa Tengah, dan Dinas Pertanian TPH Kabupaten Karanganyar.

\section{DAFTAR PUSTAKA}

Anonim. 2009. Peraturan Menteri Pertanian Nomor: 52/ Permentan/OT.140/ 12/2009 tentang Metode

Penyuluhan Pertanian. Departemen Pertanian. Jakarta. Anonim. 2014. Panduan Pelaksanaan dan Kumpulan

Materi Training of Trainer (TOT) "Metodologi

Pengkajian Penyuluhan dan Evaluasi Kinerja

Diseminasi Hasil Litkaji bagi Penyuluh Pertanian

Lingkup Balai besar Pengkajian dan Pengembangan

Teknologi Pertanian (BBP2TP) Badan Penelitan dan Pengambangan Pertanian”

Emawati, S., Lutojo, H. Irianto, T.H. Rahayu, I.A. Sari. 2012. Efektivitas model pelatihan keterampilan berbasis usaha pertanian-peternakan terpadu pasca bencana erupsi Gunung Merapi di Kecamatan Selo, Kabupaten Boyolali. Sains Peternakan 10 (2): 85 - 92.

Hamalik, O. 2005. Manajemen Pelatihan Ketenagakerjaan Pendekatan Terpadu: Pengembangan Sumber Daya Manusia. Jakarta: Bumi Aksara.

Haslinda A. and M.Y. Mahyuddin. 2009. The effectiveness of training in the public service. American Journal of Scientific Research :39 - 51. 
Jurnal AGRARIS

Mujiman, H. 2006. Manajemen Pelatihan Berbasis Belajar Mandiri. Yogyakarta: Pustaka Pelajar.

Narbuko. 2004. Metodologi Penelitian. Bumi Aksara. Jakarta.

Ooi, Ai Yee. 2007. The Determinants of Training Effectiveness in Malaysian Organizations. International Journal of Business Research.

Sastradipoera, K.. 2006. Pengembangan dan Pelatihan, Suatu Pendekatan Manajemen SDM. Bandung: Penerbit Kappa Sigma..

Siegel, S. 1994. Statistik Nonparametrik untuk Ilmu-ilmu Sosial. Jakarta: Gramedia Pustaka Utama.

Sugiyono. 2010. Statistik Nonparametrik untuk Penelitian. Bandung: Alfabeta.

Suwarto. 1999. Perilaku Keorganisasian. Yogyakarta: Universitas Atma Jaya Yogyakarta. 